\title{
Quantitative Review of the Effects of Triazole and Benzimidazole Fungicides on Fusarium Head Blight and Wheat Yield in Brazil
}

\author{
Franklin Jackson Machado, Departamento de Fitopatologia, Universidade Federal de Viçosa, 36570-000, MG, Brazil; Flávio Martins \\ Santana and Douglas Lau, Embrapa Trigo, Passo Fundo, 70770-901 RS, Brazil; and Emerson Medeiros Del Ponte, ${ }^{\dagger}$ Departamento de \\ Fitopatologia, Universidade Federal de Viçosa, 36570-000 MG, Brazil
}

\begin{abstract}
Triazole and benzimidazole fungicides have been used for controlling Fusarium head blight (FHB) in wheat for over two decades. In Brazil, it was only during the last five years that uniform fungicide trials for FHB control have been established yearly, thus contributing to a new large body of fungicide efficacy data for this country. A systematic review of both peer- and non-peer-reviewed studies on chemical control conducted since 2000 in Brazil was performed. Fungicides of interest were the triazoles tebuconazole $\left(\mathrm{TEBU}_{1 \mathrm{x}}\right.$ and $\left.\mathrm{TEBU}_{2 \mathrm{x}}\right)$ and propiconazole $\left(\mathrm{PROP}_{2 \mathrm{x}}\right)$, and the benzimidazole carbendazim $\left(\mathrm{CARB}_{2 \mathrm{x}}\right)$. Most fungicides were applied twice, the first at early to mid-flowering and the second 7 to 10 days later. Only TEBU was tested as one or two applications, and thus four treatments were evaluated. For these fungicides, there were 35 trials reporting FHB index and 48 reporting mean yield. Network meta-analytic models were fitted to the data of the log of the means of FHB index for each fungicide and for the nontreated check. The meta-analytic estimates were used to obtain control efficacy $(\bar{C})$, or percent disease reduction relative to the nontreated check. The absolute mean difference $(\bar{D})$ in yield $(\mathrm{kg} / \mathrm{ha})$ between the

fungicide-treated and the nontreated check plots was also estimated. Yield response relative to the nontreated check $(\bar{Y})$ was also calculated based on the difference in the logs of the means of yield between fungicide-treated and nontreated check. The TEBU $\mathrm{T}_{1 \mathrm{x}}, \mathrm{TEBU}_{2 \mathrm{x}}$, and $\mathrm{CARB}_{2 \mathrm{x}}$ treatments performed similarly with regards to control efficacy $(=59 \%, 53 \%$ and $55 \%$, respectively), and although better than $\mathrm{PROP}_{2 \mathrm{x}}(47 \%)$, the difference was marginally significant. Yield response $(\bar{D})$ was highest for TEBU $2 \mathrm{x}$, $(\bar{D}=558 \mathrm{~kg} / \mathrm{ha}, \bar{Y}=19.2 \%)$ followed by $\mathrm{PROP}_{2 \mathrm{x}}(497 \mathrm{~kg} / \mathrm{ha}, 16.0 \%)$, $\mathrm{TEBU}_{1 \mathrm{x}}(457 \mathrm{~kg} / \mathrm{ha}, 17.3 \%)$, and $\mathrm{CARB}_{2 \mathrm{x}}(456 \mathrm{~kg} / \mathrm{ha}, 12.8 \%)$. For an average 2016 scenario of fungicide plus application costs $\left(F_{C}=\$ 18\right.$ U.S./ha $)$ and average wheat price $\left(W_{P}=\$ 215\right.$ U.S./MT), the probability of breaking even on the financial investment in the four treatments ranged from 59 to $63 \%$. For 140 scenarios (four fungicides) created based on the combination of five $W_{P}$ ( $\$ 133$ to 266 U.S./MT) and seven $F_{C}$ ( $\$ 5$ to 35 U.S./ha), the probability of breaking even was $>50 \%$ for all but two scenarios. The information may serve as a guide for planning future trials and provides a baseline and first step toward optimizing FHB management in Brazil.
\end{abstract}

Fusarium head blight (FHB), caused mainly by the Fusarium graminearum species complex (FGSC), is among the most important fungal diseases of wheat worldwide (Goswami and Kistler 2004; McMullen et al. 2012). In the presence of airborne inoculum, the first infections may occur during the onset of flowering if wet conditions prevail. The earlier the infection, the greater the damage in grain yield because infected kernels show reduced size, light weight, and a shriveled appearance. However, postflowering infection, although less damaging to grain yield, may contribute to the accumulation of mycotoxins in the grain (Del Ponte et al. 2007; McMullen et al. 2012). FGSC members are able to produce a wide range of mycotoxins, but those of greatest concern are the trichothecenes, especially deoxynivalenol (DON), which is commonly found in commercial grain at unacceptable levels for both human and animal consumption (Del Ponte et al. 2012; McMullen et al. 2012). Maximum tolerated levels of DON in small grain and foods have been established in many countries (van Egmond et al. 2007) including Brazil (ANVISA 2011).

FHB control aims at minimizing yield losses but also reducing DON concentration in commercial wheat grain (Gilbert and Haber 2013; McMullen et al. 2012; Wegulo et al. 2015). The combination of genetic and chemical control methods has been recommended to improve control efficacy (Hollingsworth et al. 2008; Gilbert and Haber, 2013; Wegulo et al. 2015; Willyerd et al. 2012). Fungicides have been used more intensively in recent years for suppressing FHB and reducing yield losses and DON levels (Wegulo et al. 2015), particularly those within triazoles, which have shown variation in efficacy among the active ingredients (Paul et al. 2008). Benzimidazole fungicides, mainly carbendazim, have a longer history in FHB control than triazoles and are still used after more than three

${ }^{\dagger}$ Corresponding author. E-mail: delponte@ufv.br

Accepted for publication 14 May 2017.

(c) 2017 The American Phytopathological Society decades, especially in China due to their relatively lower cost compared with triazoles (Chen et al. 2015; Mesterházy et al. 2003; Sun et al. 2014). In Brazil, carbendazim has been tested and used in FHB management since the early 1980s (Deuner et al. 2011). During the early 1990s, new triazoles including tebuconazole and propiconazole were introduced to FHB management and have become standard in Brazil and worldwide (Deuner et al. 2011; McMullen et al. 2012).

In the U.S., one application of triazoles at flowering is usually recommended for maximizing control efficacy under conditions favorable for the disease (D'Angelo et al. 2014; McMullen et al. 1997; Paul et al. 2010). There are several options within the triazole group and there are clear differences among the active ingredients within the group. For example, a meta-analysis of fungicide trial data obtained during 11 years showed superior control by prothioconazole + tebuconazole, metconazole, and prothioconazole, where control was 10 to 20 percentage points higher than tebuconazole with regards to FHB index (Paul et al. 2008). Accordingly, these fungicides have led to mean yield responses from 420 to $450 \mathrm{~kg} / \mathrm{ha}$, or $14 \%$ relative to nontreated check, as suggested by a subsequent meta-analysis (Paul et al. 2010). In Europe, tebuconazole usually outperforms carbendazim in FHB control, with overall efficacy estimated around 50\% for the former and 35\% for the latter (Mesterházy et al. 2003). It is generally acknowledged that yield responses to a second fungicide spray at postflowering targeting FHB seem to rarely offset the increased application costs, but the economics are not fully explored (D'Angelo et al. 2014; McMullen et al. 1997; Paul et al. 2010). In Brazil, one or two sprays of the triazole and strobilurins mixture (metconazole + pyraclostrobin) and a triazole alone (metconazole) were compared in four trials. Although control efficacy was not improved, yield response was higher with the additional fungicide spray but only when all treatments were combined, including the premix (Spolti et al. 2013). Even though it is not clear whether an additional spray is profitable, two sprays (at flowering and 7 to 10 days later) are recommended and tested more often than one spray in Brazilian trials. The strategy is likely due to the need of extended protection against foliar diseases provided by premixes of strobilurin and triazole fungicides (Wegulo et al. 2011). 
A narrative review on the use of fungicides in FHB management in Brazil summarized data on mean percent reduction of FHB incidence and index across 19 commercial fungicides applied alone or in combination in eight studies conducted from 1982 to 2009 (Deuner et al. 2011). The overall mean percent control (all fungicides combined) was $50 \%$ and $70 \%$ for incidence and severity, respectively; however, there was large variation within and among fungicides. Starting in 2011, uniform fungicide trials (UFTs) have been established and conducted yearly by a network of wheat pathologists in the main wheat regions of southern Brazil. The main goal of the cooperative network is to monitor the performance of a common set of fungicides, including current recommendations and new fungicides and using a standard protocol within the season (Santana et al. 2012, 2014, 2016a, b, c).

An updated quantitative summary using the recently collected data combined with statistical methods that allow estimating the magnitude and uncertainty of the effect, such as meta-analysis, is appealing. Meta-analysis can be defined as a statistical synthesis of results from primary studies obtained from peer- or non-peer-reviewed publications, which account for within- and among-study variability using a statistically robust framework (Borenstein et al. 2009; Madden and Paul 2011). The method has been used more recently in quantitative summaries of treatment effects on plant disease reduction and yield response (Ngugi et al. 2011; Ojiambo et al. 2010; Paul et al. 2007, 2008, 2011; Scherm et al. 2009). Meta-analytic estimates of yield response to fungicides have been based on economic analysis such as the probability of breaking even or not offsetting fungicide costs for the control of foliar maize diseases (Paul et al. 2011; Tedford et al. 2017). Traditionally, meta-analysis is usually preceded by a systematic review of multiple literature sources including peerand non-peer-reviewed studies, from which aggregated statistics are obtained directly from reported data (Madden et al. 2016).

In this study, a multitreatment (or network) meta-analysis was used to combine results of fungicide effects on FHB control and

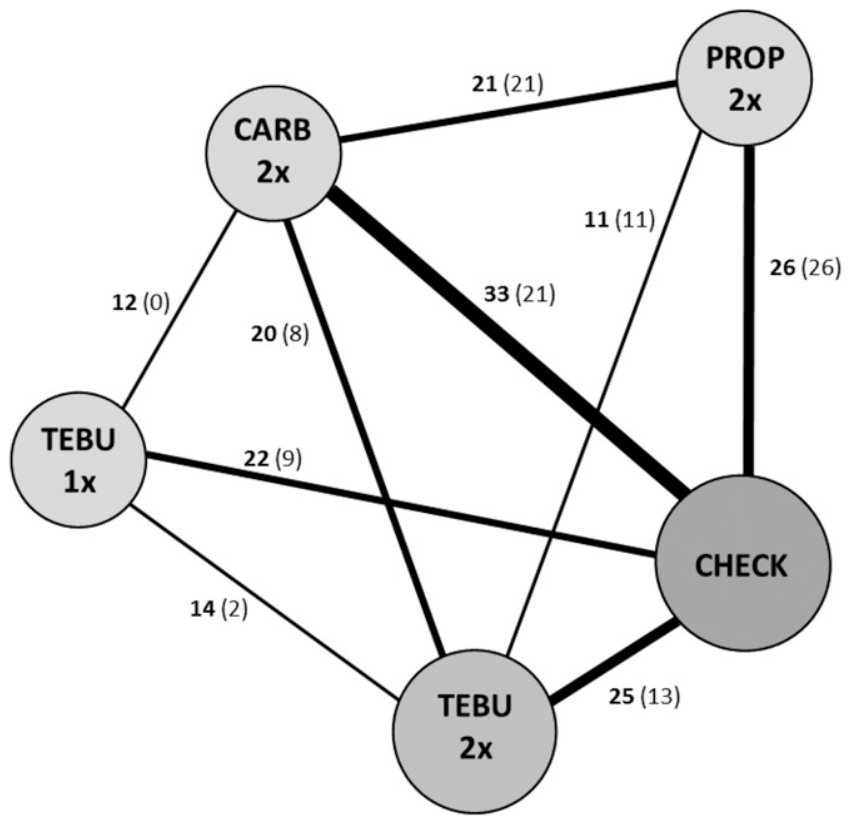

Fig. 1. Network of co-occurrences of treatments for Fusarium head blight (FHB) control on wheat from a systematic review of peer- and non-peer-reviewed studies conducted in Brazil. There were four fungicides, which included carbendazim $\left(\mathrm{CARB}_{2 \times}\right)$, propiconazole $\left(\mathrm{PROP}_{2 \times}\right)$, and tebuconazole $\left(\mathrm{TEBU}_{1 \times}\right.$ or $\left.\mathrm{TEBU}_{2 \times}\right)$, and a nontreated check (CHECK) across a total of 48 trials reporting yield and 35 trials reporting FHB index. The number of co-occurrences for each two treatment combination is depicted next to the links (edges) of the two treatments. Numbers outside and within parenthesis refers to number of trials reporting yield and severity, respectively. The suffix $1 \times$ refers to a single spray at early to midflowering and suffix $2 \times$ refers to two sprays (first spray at early to mid-flowering and the second 7 to 10 days later) wheat yield. With this approach, the treatments of interest that generally occur in the same trial are simultaneously analyzed, which allows for direct comparisons between them, while taking into account all the correlations (Madden et al. 2016; Paul et al. 2008). The metaanalysis was preceded by systematic review of peer- and non-peerreviewed studies conducted in Brazil during the last 15 years. In addition, to estimate the overall effect of different fungicides on control efficacy and yield response, we investigated factors that could explain, at least in part, the amount of expected heterogeneity in fungicide efficacy and yield response data. Finally, using the estimated yield response, the probability of breaking even on the financial investment in specific fungicide treatments, applied once or twice, was calculated based on a range of wheat prices and fungicide costs.

\section{Materials and Methods}

Literature search and criteria for inclusion. A systematic review of peer- and non-peer-reviewed articles/reports (hereafter studies) reporting fungicide field testing data in Brazil was performed for the last 16 years (2000 to 2016). To be included, a study had to have a measure of disease intensity (incidence or severity, hereafter FHB index) and/or a measure of wheat grain yield in both fungicide-treated and nontreated check plots. A total of 29 (five peer-reviewed and 24 nonpeer-reviewed) studies were found. Four studies were excluded for not reporting disease intensity and one study was excluded for not reporting yield. Hence, disease data were originated from 76 trials in 25 studies, and the yield data were originated from 86 trials in 28 studies.

Fungicide selection. The two most frequently tested triazoles were propiconazole applied twice $\left(\mathrm{PROP}_{2 \mathrm{x}}\right)$ and tebuconazole applied once $\left(\mathrm{TEBU}_{1 \mathrm{x}}\right)$ or twice $\left(\mathrm{TEBU}_{2 \mathrm{x}}\right)$ in at least nine independent trials. The only benzimidazole found in the review was carbendazim applied twice $\left(\mathrm{CARB}_{2 \mathrm{x}}\right)$. When one spray was applied (case of TEBU), this was made at flowering. For two applications, the first was from early to mid-flowering and the second 7 to 10 days later. Among the triazoles, metconazole has also been tested but there were only six trials, with one peer-reviewed study contributing four trials (Spolti et al. 2013). Therefore, the total number of trials used in our analysis was reduced to 35 (12 studies) and 48 trials ( 15 studies) for FHB index and yield data, respectively, which also tested at least one of the selected fungicides $\left(\mathrm{TEBU}_{1 \mathrm{x}}, \mathrm{TEBU}_{2 \mathrm{x}}, \mathrm{PROP}_{2 \mathrm{x}}\right.$, or $\left.\mathrm{CARB}_{2 \mathrm{x}}\right)$. In a selected study, at least one of the treatments and the nontreated check was tested in a same trial, but there were eight different trial designs (co-occurrences of treatments in a same trial), which provided a network of both direct and indirect evidence of the difference between treatments (Madden et al. 2016) (Fig. 1).

The within-study variability (sampling variance) was calculated from the coefficient of variation (CV) or the least significant difference (LSD) reported for each selected trial. In $31 \%$ of the trials, these statistics were not available, but only multiple comparisons of means were available. For these, the LSD was estimated using an empirical approach (Ngugi et al. 2011). For 13 trials (27\%) with no reports of any of the above measures, the sampling variance was estimated by fitting a linear regression model, similarly to previous work (Paul et al. 2007) to the relationship between the variance and the mean FHB index or yield. This model provided good fit to the data (data not shown).

Response variables. Three response variables of interest were obtained: 1) percent control efficacy $(\bar{C})$ of FHB index relative to the nontreated check. There were four studies that reported only FHB incidence. For those, FHB index was estimated from incidence using a complementary log-log model developed with data collected in the same region across 160 fields (Spolti et al. 2015). Variable 2) is the absolute difference $(\bar{D})$ in wheat yield between the fungicide treatment and the nontreated check. The latter metric can be used when the variation in the reference treatment (e.g., nontreated check) across studies is not large (Madden and Paul 2011; Paul et al. 2010). In our study, the calculated coefficients of variation were $131 \%$ and $38 \%$ for FHB index and yield in the nontreated check, thus supporting the use of $D$ for yield data. For variable 3 ) the percent yield increase $(\bar{Y})$ relative to the nontreated check was also calculated (Paul et al. 2010). The estimated variances ( $V$ ) (within-study or sampling 
variance) of the $\log$ of treatment means and $D$ were estimated as described (Paul et al. 2008, 2010).

Network meta-analytic model. A multivariate or network model was fitted to the data because selected treatments were evaluated simultaneously in the same trial, and so the correlations of estimated treatment effects are taken into account. The approach used here is called a two-way unconditional linear mixed model because it was fitted directly to the treatments means (absolute or logtransformed) and not to the pairwise differences of treatment means (Madden et al. 2016; Paul et al. 2008). The model can be written as:

$$
\mathbf{Y}_{i} \sim N\left(\boldsymbol{\mu}, \boldsymbol{\Sigma}+\mathbf{S}_{i}\right)
$$

where $\mathbf{Y}_{i}$ is the vector of $L$ ( $\log$ of the means of severity or yield) or mean yield for the four treatments plus the nontreated check for the $i$ th study, $\boldsymbol{\mu}$ is a vector representing the mean of $\mathbf{Y}_{i}$ across all studies, $\Sigma$ is a $5 \times 5$ between-study variance-covariance matrix, and $S_{i}$ is within-study variance-covariance matrix for the $i$ th study. $N(\bullet)$ indicates a multivariate normal distribution. The elements of $\mathbf{S}_{i}$ were incorporated into the model fitting procedure as weights calculated as the inverse function of the within-study variance for each treatment from each study as described (Paul et al. 2008). An unstructured $\Sigma$ matrix was used and the models were fitted to the data with a maximum-likelihood parameter. The model was fitted using the "metafor" package (Viechtbauer 2010) of R (R Core Team 2012). To test for inconsistency of the network, for both the estimates of the log of the means of FHB index and nontransformed means of yield, all trials were categorized according to their design or the common set of treatments tested in the trial. In total, eight different designs were found for testing the fungicide effects on both variables. A significant interaction of the treatment and design factors, tested in meta-analytic model as described, evaluated based on the Wald test statistic, was an indication of inconsistency (Madden et al. 2016; Piepho et al. 2015).

Control efficacy and yield response. Since the log of the response ratios equal the difference of logs, the differences between pairs of the elements in $\mu$, as well as their standard errors and $95 \%$ confidence intervals were obtained (Paul et al. 2008). Thus, the overall mean log of the response ratio $(\bar{L})$ for each fungicide treatment relative to the nontreated check was estimated as $\bar{L}=\hat{\mu}_{\text {Treat }}-\hat{\mu}_{\text {Check }}$, where $\hat{\mu}_{\text {Treat }}$ and $\hat{\mu}_{\text {Check }}$ are estimated mean $\log$ FHB index or yield for a treatment (Treat) and the nontreated check ( ${ }_{\text {Check }}$ ), respectively. Overall mean percent FHB control and mean yield increase and their confidence intervals were obtained by back-transforming $\bar{L}_{\mathrm{IND}}$ and $\bar{L}_{\mathrm{YLD}}$ and the upper and lower limits of the confidence intervals around $\bar{L}_{I N D}$ and $\bar{L}_{Y L D}$ as $\bar{C}=\left(1-\left(\exp \left(\bar{L}_{I N D}\right)\right) \times 100\right)$ and $\bar{Y}=\left(\left(\exp \left(\bar{L}_{Y L D}\right)-1\right) \times 100\right)$, respectively. The mean difference in yield $(\bar{D})$ was estimated directly by the difference between the estimates for the fungicide treatment and the nontreated check (Madden et al. 2016).

Effect of moderator variables. The network meta-analysis model was expanded to evaluate if the heterogeneity in the effect-sizes could be explained, at least in part, by study-specific categorical and continuous moderator variables (Paul et al. 2008, 2010, 2011). Linear contrasts were used to estimate the mean effect sizes and their standard errors and 95\% CIs for each level of the categorical moderator (Madden et al. 2016; Paul et al. 2011).

The trial-specific environmental and management conditions defined two categorical variables, which were considered baselines for FHB index $\left(\mathrm{FHB}_{\text {base }}\right)$ and yield $\left(\mathrm{YLD}_{\text {base }}\right)$. In the first case, FHB index of $7 \%$ in the nontreated check separated two groups of trials with the nontreated check plots experiencing low $\left(\mathrm{FHB}_{\text {low }}, \leq 7 \%\right)$ or high $\left(\mathrm{FHB}_{\text {high }},>7 \%\right)$ disease intensity. The threshold of $7 \%$ was the median of the distribution of FHB index in the nontreated check, and is also similar to threshold for epidemic classifications. For example, in the United States, a 10\% FHB index threshold was used to classify the disease in epidemic and "non-epidemic" cases (De Wolf et al. 2003) and 7\% FHB index was used to separate light from moderate epidemic levels (Del Ponte et al. 2005). Baseline for yield separates trials with yield below average $\left(\mathrm{YLD}_{\text {low }} \leq 3,000 \mathrm{~kg} /\right.$ ha) or above average $\left(\mathrm{YLD}_{\text {high }}>3,000 \mathrm{~kg} / \mathrm{ha}\right.$ ) yield in the nontreated check. The 3,000 kg/ha threshold was close to the median yield in the nontreated check. We tested whether FHB index in the nontreated check, treated as a continuous variable (without grouping), significantly affected estimated yield for each fungicide treatment. Year was also tested as a continuous variable to verify whether there was a trend of decreasing control efficacy over the years.

Probability of breaking-even fungicide application cost. The mean yield difference $(\bar{D})$ and the between-study variance $\left(\hat{\tau}^{2}\right)$ estimated by the meta-analytic models were used to calculate the probability of breaking even when considering the fungicide application $\operatorname{cost}\left(F_{C}=\right.$ fungicide plus application costs). This was calculated as the cumulative standard-normal distribution function of $[(\bar{D}-$ $\left.\left.F_{C} / W_{P}\right) / \sqrt{\hat{\tau}^{2}}\right]$ as in previous studies (Paul et al. 2011; Salgado et al. 2014; Tedford et al. 2017). The operational costs were fixed at $\$ 10$ U.S./ha. Average prices of triazoles (PROP or TEBU) and CARB were $\$ 8.9$ and $\$ 7.9$ U.S./ha, respectively, considering the average exchange rate of $\$ 3.16 \mathrm{BRL}=\$ 1$ USD during September 2016. The average wheat price $\left(W_{P}\right)$ used in our analysis was $\$ 215$ U.S./MT $(\$ 680$ BRL) according to estimates for that same growing season. Given the variability of prices and costs at the farm-level and across years, we further calculated the probabilities of breaking even for a range of $W_{P}$ (\$133 to 266 U.S./MT) and $F_{C}$ (\$5 to 35 U.S./ha) values.

Data and code availability. All data and the R scripts used to prepare, summarize, and analyze the data, as well as to produce the plots, are freely available on a GitHub repository (https://github. com/emdelponte/paper-FHB-Brazil-meta-analysis).

\section{Results}

Characteristics of the selected studies and trials. Fifty percent of the trial data were obtained from technical reports of the cooperative network trials ( 15 reports that included 48 independent trials), followed by extended abstracts that reported efficacy and/or yield data $(35 \%)$. Only a small portion $(15 \%)$ was obtained from peerreviewed articles (Table 1). The selected trials were conducted in 15 municipalities that predominated in the state of Rio Grande do Sul $(71 \%)$, followed by Paraná $(23 \%)$ and Santa Catarina $(6 \%)$, all in southern Brazil. Although the time period spanned 11 years, $83 \%$ of the trials were conducted after 2010. Twenty-four cultivars possessing variable levels of resistance were used in these trials, but most of them were classified as moderately susceptible (31/48 trials). These and other characteristics of each trial are summarized in Table 1.

FHB index and wheat yield. The mean FHB index in the nontreated check plots varied significantly across the trials, but it was generally lower than $10 \%$ (median $=6.9 \%$ ). In only nine out of 35 trials, FHB index was greater than $30 \%$. As expected, the mean FHB index in a single trial was generally lower in the fungicidetreated plots compared with the nontreated check (Fig. 2A). Conversely, wheat yield was generally lower in the nontreated check plots than in the fungicide-treated plots, but also varied largely across the trials (Fig. 2B).

Overall fungicide efficacy. The estimated overall mean for the $\log$ of FHB index for the fungicide treatment $\left(\bar{L}_{\text {IND }}\right)$ differed significantly from zero, based on the standard normal test $(Z)(P<0.001)$ (Table 2). The lowest (most negative) $\bar{L}_{\text {IND }}$ was estimated for $\mathrm{TEBU}_{1 \mathrm{x}}$, followed by $\mathrm{CARB}_{2 \mathrm{x}}, \mathrm{TEBU}_{2 \mathrm{x}}$, and $\mathrm{PROP}_{2 \mathrm{x}}$. However, linear contrasts showed no difference between $\bar{L}_{\mathrm{IND}}$ estimated for TEBU $_{\mathrm{x}}$ and TEBU ${ }_{2 \mathrm{x}}(P=0.2775)$. The difference in $\bar{L}_{\mathrm{IND}}$ between PROP $_{2 \mathrm{x}}$ and $\mathrm{CARB}_{2 \mathrm{x}}(P=0.0491)$ and $\mathrm{PROP}_{2 \mathrm{x}}$ and TEBU ${ }_{1 \mathrm{x}}(P=$ $0.0607)$ were marginally significant. No significant difference in $\bar{L}_{\text {IND }}$ was found between $\operatorname{PROP}_{2 \mathrm{x}}$ and TEBU $\mathrm{Tx}_{2 \mathrm{x}}(P=0.0909)$. The estimated $\bar{C}$, from back-transforming $\bar{L}_{\mathrm{IND}}$, differed by three percentage points between TEBU ${ }_{1 \mathrm{x}}$ (and TEBU $\mathrm{T}_{2 \mathrm{x}}$ ) and CARB. Mean estimated $\bar{C}$ for PROP $_{2 \mathrm{x}}$ was 11.6 percentage points lower than $\mathrm{TEBU}_{1 \mathrm{x}}$ and 6.3 percentage points lower than $\mathrm{TEBU}_{2 \mathrm{x}}$ (Table 2).

Overall yield response. There was large variation across the trials for the absolute difference in yield $(D)$ between fungicide treatment and the nontreated check. The maximum range averaged $1,550 \mathrm{~kg} / \mathrm{ha}$ across the three fungicides (Fig. 3). In the great majority of cases, mean yield in the fungicide-treated plot was higher than the mean 
of the nontreated check, except for six entries (4.3\%, six out of 140 entries excluded the nontreated check) in three trials $(6 \%$, three out of 48 trials) for which $D$ was negative (Fig. 3 ).

The overall $\bar{D}$ estimated by the meta-analytic model differed significantly from zero for each treatment, based on the standard normal test $(Z)$ in the meta-analysis $(P<0.001)$. The estimated mean $\bar{D}$ values were positive for $\mathrm{CARB}_{2 \mathrm{x}}(456 \mathrm{~kg} / \mathrm{ha}), \mathrm{PROP}_{2 \mathrm{x}}(497 \mathrm{~kg} / \mathrm{ha})$, $\mathrm{TEBU}_{1 \mathrm{x}}(457 \mathrm{~kg} / \mathrm{ha})$, and TEBU ${ }_{2 \mathrm{x}}(558 \mathrm{~kg} / \mathrm{ha}$ ) (Table 3). Similarly, the estimated mean of the relative yield response $\left(\bar{L}_{\mathrm{YLD}}\right)$, for all fungicides, differed significantly from zero based on the standard normal test $(Z)(P<0.001)$. Marginally significant differences in $\bar{L}_{\mathrm{YLD}}$ were found between $\mathrm{PROP}_{2 \mathrm{x}}$ and $\mathrm{CARB}_{2 \mathrm{x}}(P=0.0332)$ and $\mathrm{PROP}_{2 \mathrm{x}}$ and $\mathrm{TEBU}_{2 \mathrm{x}}(P=0.0403)$. However, $\bar{L}_{\mathrm{YLD}}$ did not differ between PROP $_{2 \mathrm{x}}$ and $\operatorname{TEBU}_{1 \mathrm{x}}(P=0.4861)$. The highest $\bar{Y}(19.2 \%)$ was estimated for $\mathrm{TEBU}_{2 \mathrm{x}}$, followed by TEBU $\mathrm{Tx}_{\mathrm{x}}(17.3 \%), \operatorname{PROP}_{2 \mathrm{x}}(16.0 \%)$, and $\mathrm{CARB}_{2 \mathrm{x}}(12.8 \%)$ (Table 3$) . \bar{Y}$ was not affected by whether

Table 1. Summary information for 48 trials selected following a systematic review of peer- and non-peer-reviewed studies conducted between 2000 to 2015 in southern Brazil. These studies tested, among other treatments, the effect of two sprays (first at flowering and a second 7 to 10 days later) of tebuconazole, propiconazole, and carbendazim or one spray (at early to mid-flowering) of tebuconazole for suppressing Fusarium head blight (FHB) index and/or increasing grain yield (YLD).

\begin{tabular}{|c|c|c|c|c|c|c|c|c|}
\hline $\mathbf{S}^{\mathbf{a}}$ & $\mathbf{T}^{\mathbf{b}}$ & HYc & Municipality, State ${ }^{d}$ & Cultivar & FHB reaction ${ }^{\mathrm{e}}$ & Number of sprays ${ }^{f}$ & $\mathbf{F H B}_{\text {Check }}(\%)$ & YLD $_{\text {Check }}(\mathrm{kg} / \mathrm{ha})$ \\
\hline 1 & 1 & 2000 & Passo Fundo, RS & BRS 23 & MS & 1 versus 2 & 38.8 & 2,838 \\
\hline 1 & 2 & 2000 & Passo Fundo, RS & BRS 23 & MS & 1 versus 2 & 34.9 & 3,085 \\
\hline 2 & 3 & 2000 & Passo Fundo, RS & BRS 23 & MS & 1 & 38.8 & 2,838 \\
\hline 2 & 4 & 2000 & Passo Fundo, RS & BRS 23 & MS & 1 & 34.9 & 3,085 \\
\hline 3 & 5 & 2004 & Muitos Capões, RS & BRS Louro & MR & 1 & 5.9 & 4,984 \\
\hline 3 & 6 & 2005 & Lages, SC & BRS Louro & MR & 1 & 12.7 & 1,835 \\
\hline 4 & 7 & 2009 & Cruz Alta, RS & Fundacep Nova Era & MS & 1 & - & 590 \\
\hline 5 & 8 & 2010 & Toledo, PR & CD114 & MS & 1 & 4.1 & 2,847 \\
\hline 6 & 9 & 2011 & Castro, PR & BRS 208 & MS & 2 & 13.7 & 3,610 \\
\hline 6 & 10 & 2011 & Cruz Alta, RS & BRS 208 & MS & 2 & 7.7 & 2,718 \\
\hline 6 & 11 & 2011 & Passo Fundo, RS & BRS 208 & MS & 2 & 1.3 & 2,569 \\
\hline 6 & 12 & 2011 & Condor, RS & BRS 208 & MS & 2 & 3.8 & 3,050 \\
\hline 6 & 13 & 2011 & Lages, SC & BRS 208 & MS & 2 & 0.5 & 4,190 \\
\hline 6 & 14 & 2011 & Guarapuava, PR & BRS 208 & MS & 2 & 10.0 & 4,198 \\
\hline 6 & 15 & 2011 & Ponta Grossa, PR & BRS 208 & MS & 2 & 1.1 & 2,993 \\
\hline 7 & 16 & 2012 & Ponta Grossa, PR & BRS 208 & MS & 2 & 3.0 & 2,024 \\
\hline 7 & 17 & 2012 & Ponta Grossa, PR & BRS 208 & MS & 2 & 6.3 & 4,033 \\
\hline 7 & 18 & 2012 & Cruz Alta, RS & BRS 208 & MS & 2 & 8.7 & 3,015 \\
\hline 7 & 19 & 2012 & Capão Bonito do Sul, RS & BRS 208 & MS & 2 & 6.6 & 793 \\
\hline 7 & 20 & 2012 & Passo Fundo, RS & BRS 208 & MS & 2 & 1.8 & 2,673 \\
\hline 7 & 21 & 2012 & Guarapuava, PR & BRS 208 & MS & 2 & 16.5 & 3,331 \\
\hline 8 & 22 & 2013 & Passo Fundo, RS & BRS 208 & MS & 2 & 6.0 & 3,591 \\
\hline 8 & 23 & 2013 & Passo Fundo, RS & BRS 208 & MS & 2 & 7.0 & 3,478 \\
\hline 8 & 24 & 2013 & Giruá, RS & Campeiro & MS & 2 & 8.0 & 2,108 \\
\hline 8 & 25 & 2013 & Capão Bonito do Sul, RS & Campeiro & MS & 2 & 6.0 & 2,115 \\
\hline 8 & 26 & 2013 & Cruz Alta, RS & Fundacep Bravo & MS & 2 & 2.0 & 3,996 \\
\hline 8 & 27 & 2013 & Guarapuava, PR & BRS Guabijú & MS & 2 & 62.0 & 3,756 \\
\hline 9 & 28 & 2013 & Guarapuava, PR & BRS Guamirim & MR & 1 & 50.0 & 4,393 \\
\hline 10 & 29 & 2013 & Guarapuava, PR & CD105 & $\mathrm{S}$ & 2 & 62.0 & 3,756 \\
\hline 11 & 30 & 2014 & Coxilha, RS & Taurum & $\mathrm{S}$ & 1 versus 2 & - & 1,836 \\
\hline 11 & 31 & 2014 & Coxilha, RS & TBIO Alvorada & MR & 1 versus 2 & - & 3,122 \\
\hline 11 & 32 & 2014 & Coxilha, RS & Mirante & $\mathrm{S}$ & 1 versus 2 & - & 3,557 \\
\hline 11 & 33 & 2014 & Coxilha, RS & TBIO Toruk & MS & 1 versus 2 & - & 3,716 \\
\hline 12 & 34 & 2014 & Água Santa, RS & TBIO Sinuelo & MS & 2 & 6.6 & 3,159 \\
\hline 12 & 35 & 2014 & Cruz Alta, RS & TEC 10 & MS & 2 & 8.8 & 2,077 \\
\hline 12 & 36 & 2014 & Giruá, RS & Fundacep Nova Era & MS & 2 & 90.0 & 1,209 \\
\hline 12 & 37 & 2014 & Londrina, PR & BRS Graúna & $\mathrm{MS} / \mathrm{S}$ & 2 & 92.2 & 67 \\
\hline 12 & 38 & 2014 & Ponta Grossa, PR & TBIO Itaipu & MS & 2 & 0.6 & 3,429 \\
\hline 13 & 39 & 2007 & Cruz Alta, RS & Fundacep52 & $\mathrm{S}$ & 1 & 7.3 & 1,165 \\
\hline 14 & 40 & 2013 & Coxilha, RS & Abalone & MS/MR & 1 versus 2 & - & 4,683 \\
\hline 14 & 41 & 2013 & Coxilha, RS & TBIO Alvorada & MR & 1 versus 2 & - & 4,897 \\
\hline 14 & 42 & 2013 & Coxilha, RS & TBIO Mestre & MS & 1 versus 2 & - & 5,114 \\
\hline 14 & 43 & 2013 & Coxilha, RS & Mirante & $\mathrm{S}$ & 1 versus 2 & - & 4,398 \\
\hline 14 & 44 & 2013 & Coxilha, RS & Quartzo & MS & 1 versus 2 & - & 4,487 \\
\hline 14 & 45 & 2013 & Coxilha, RS & TBIO Sinuelo & MS & 1 versus 2 & - & 4,757 \\
\hline 14 & 46 & 2013 & Coxilha, RS & TBIO Iguaçu & MS/MR & 1 versus 2 & - & 4,233 \\
\hline 14 & 47 & 2013 & Coxilha, RS & Taurum & $\mathrm{S}$ & 1 versus 2 & - & 2,762 \\
\hline 15 & 48 & 2013 & Itapiranga, SC & BRS 208 & MS & 2 & 6.5 & 3,187 \\
\hline
\end{tabular}

a Study number (S): 1 = Panisson et al. (2002), 2 = Panisson et al. (2003), 3 = Casa et al. (2007), $4=$ Silva et al. $(2010), 5=$ Correa et al. $(2012), 6=$ Santana et al. (2012), 7 = Santana et al. (2014), $8=$ Santana et al. (2016a), $9=$ Feksa et al. (2014a), $10=$ Feksa et al. $(2014 b), 11=$ Tonin et al. $(2015), 12=$ Santana et al. (2016c), 13 = Deuner (2009), 14 = Tonin et al. (2014), and $15=$ Feldmann et al. (2014).

b Trial number $(\mathrm{T})$.

c Harvest year (HY)

d States: RS = Rio Grande do Sul, SC = Santa Catarina, and PR = Paraná.

e Resistance level to FHB according to breeder's classification: $\mathrm{S}=$ susceptible, $\mathrm{MS}=$ moderately susceptible, $\mathrm{MR}=$ moderately resistant, $\mathrm{MS} / \mathrm{MR}=$ intermediate between $M S$ and $M R$, and MR/R = intermediate between MR and resistant $(\mathrm{R})$.

f $1=$ one spray at early or mid-anthesis, 2 = first spray at early or mid-anthesis and second 7 to 10 days after. 
TEBU was applied once or twice $(P=0.2011)$. Conversely, the estimated absolute difference $(\bar{D})$ of $102 \mathrm{~kg} /$ ha between TEBU $_{2 \mathrm{x}}$ and $\mathrm{TEBU}_{1 \mathrm{x}}$ was marginally significant $(P=0.0356)$ (Table 3$)$. The difference in $\bar{L}_{\mathrm{YLD}}$ between $\mathrm{PROP}_{2 \mathrm{x}}$ and $\mathrm{CARB}_{2 \mathrm{x}}$ or TEBU sprayed once or twice was not significant $(P>0.1)$. Based on the Wald test
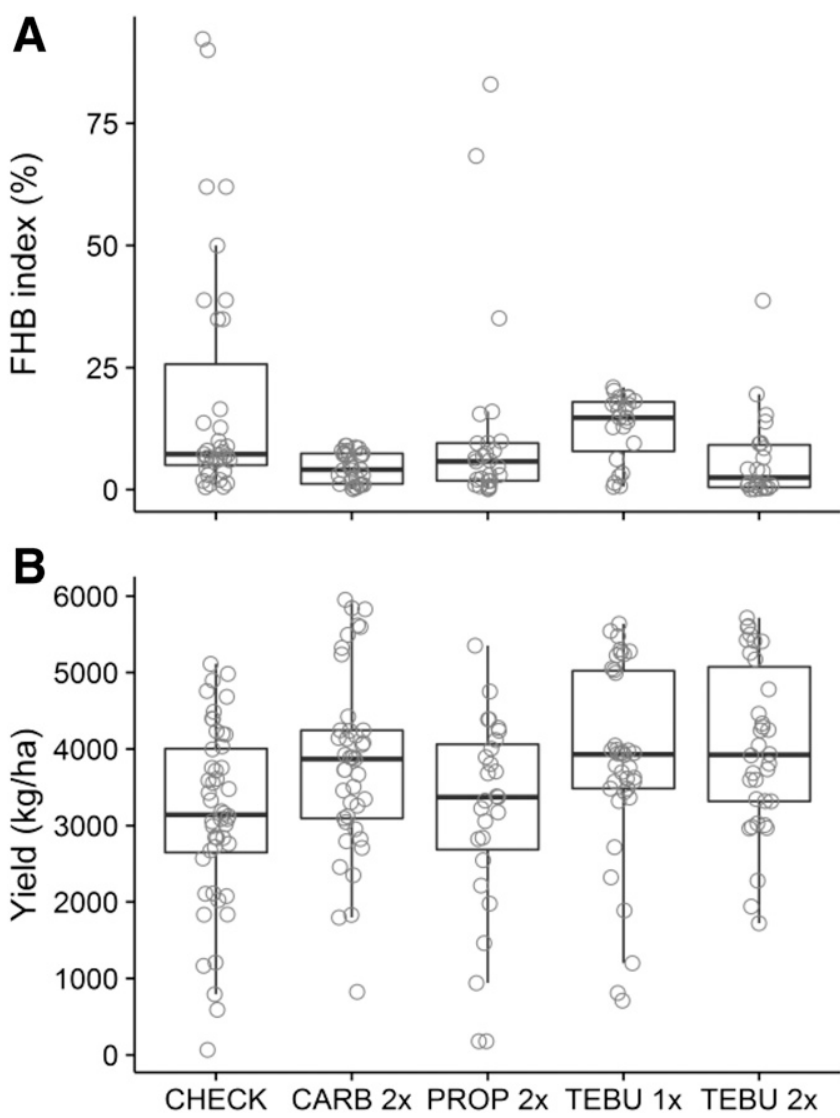

Fig. 2. Box plots and individual means of $\mathbf{A}$, Fusarium head blight index and $\mathbf{B}$, grain yield across replicated (4 to 5 ) wheat plots in trials selected based on a systematic review of peer- and non-peer-reviewed studies conducted in Brazil. The treatments consisted of a nontreated (CHECK) or treated with two sprays (first spray at early to mid-flowering and a second 7 to 10 days later) of carbendazim $\left(\mathrm{CARB}_{2 \times}\right)$, propiconazole $\left(\mathrm{PROP}_{2 \times}\right)$, or tebuconazole $\left(\mathrm{TEBU}_{2 \times}\right)$ or one spray of tebuconazole $\left(T E B U_{1 \times}\right)$ at early to mid-flowering. The line within the box represents the median, whereas the top and bottom lines of the boxes represent the 75th and 25th percentiles of the data, respectively. The vertical bars extending beyond the boxes represent a 10th and 90th percentiles and the circles represents each treatment mean, and circles beyond the bars indicate outliers. statistic, no significant design-by-treatment interaction was found $(P=0.999)$, suggesting lack of inconsistency within the present network.

Effect of moderator variables. The two categories of $\mathrm{FHB}_{\text {base }}$ and $\mathrm{YLD}_{\text {base }}$ did not affect FHB index or yield $(P>0.05)$. The same was found for the two variables treated as continuous; FHB index in the nontreated check did not affect yield $(P=0.736)$ and year did not affect FHB index $(P=0.1456)$

Probability of breaking even on the financial investment in fungicide application. For the average costs of triazoles and CARB sprays (fungicide price plus application cost) of \$18.9 U.S./ha and $\$ 17.9$ U.S./ha, and average wheat price of \$215 U.S./MT, the probability of breaking even on the cost of $\mathrm{CARB}_{2 \mathrm{x}}, \mathrm{PROP}_{2 \mathrm{x}}, \mathrm{TEBU}_{1 \mathrm{x}}$, and $\mathrm{TEBU}_{2 \mathrm{x}}$ was $58.9,60.3,62.7$, and $62.8 \%$, respectively. In general, the probability of breaking even on the fungicide application cost was affected by a range of scenarios and the variation in the cost of one or two (TEBU) applications and wheat prices (Fig. 4). For example, for two sprays of TEBU, the probability ranged from $51 \%$ (highest fungicide cost, lowest wheat price) to $67.1 \%$ (lowest fungicide cost, highest wheat price), and 57 to $65 \%$ for the same fungicide applied once. Breaking-even probability was estimated to be less than $50 \%$ only in cases where $\mathrm{CARB}_{2 \mathrm{x}}$ and $\mathrm{PROP}_{2 \mathrm{x}}$ were applied at the highest fungicide cost and lowest wheat price (Fig. 4).

\section{Discussion}

Worldwide, among the options available for optimizing the chemical control of FHB, one spray of a triazole applied at full flowering has been usually recommended, but differences among the triazoles and between triazoles and other chemistry have been reported (McMullen et al. 2012; Mesterházy et al. 2003; Paul et al. 2008, 2010; Wegulo et al. 2015). Using a meta-analytic approach, the estimated mean FHB control efficacy in Brazil ranged from 46.9 to $58.5 \%$, depending on the fungicide and number of treatments. The estimates of control efficacy for TEBU, either applied once or twice, and PROP applied twice were higher than those reported in a U.S. meta-analytic study (Paul et al. 2008). Although similar in the meta-analytical framework, our study included one or two sprays $\left(\mathrm{TEBU}_{1 \mathrm{x}}\right.$ or $\mathrm{TEBU}_{2 \mathrm{x}}$ ) or only two sprays $\left(\mathrm{PROP}_{2 \mathrm{x}}\right)$, while in Paul et al. (2008) only entries of one spray and both spring and winter wheat were tested. We found that both $\mathrm{PROP}_{2 \mathrm{x}}$ and $\mathrm{TEBU}_{1 \mathrm{x}}$ (or $\mathrm{TEBU}_{2 \mathrm{x}}$ ) performed better in Brazil than in the U.S. where percent control was 13 percentage points lower considering the spring wheat (Paul et al. 2008), which is the type used in Brazil. Interestingly, the mean control efficacy for TEBU ${ }_{1 \mathrm{x}}$ reported here $(\sim 58 \%)$ was similar to the best treatment in the U.S., which was prothioconazole applied alone $(53.7 \%)$ or as premix with tebuconazole (57.2\%) (Paul et al. 2008). Such differences may be partially explained by the additional fungicide spray at 10 days after flowering, especially for PROP. Interestingly, the number of TEBU sprays did not affect FHB control in our study, and a single application of TEBU led to

Table 2. Log of the means (effect size) estimated by a network meta-analytic model, calculated control efficacy (\% disease reduction relative to nontreated check), and related statistics for the effect of four fungicide treatments on Fusarium head blight (FHB) index in trials selected following a systematic review of peer- and non-peer-reviewed studies conducted in southern Brazil from 2000 to 2015

\begin{tabular}{|c|c|c|c|c|c|c|c|c|c|c|c|}
\hline \multirow[b]{2}{*}{ Fungicide $^{\mathbf{a}}$} & \multirow[b]{2}{*}{$N^{\mathbf{b}}$} & \multirow[b]{2}{*}{$k^{\mathbf{c}}$} & \multicolumn{6}{|c|}{ Effect size ${ }^{d}$} & \multicolumn{3}{|c|}{ Control efficacy $(\%)^{\mathrm{e}}$} \\
\hline & & & $\bar{L}_{\text {IND }}$ & se $\left(\bar{L}_{\mathbf{I N D}}\right)$ & $C I_{L}$ & $C I_{U}$ & $Z$ & $P$ & $\overline{\boldsymbol{C}}$ & $C I_{L}$ & $C I_{U}$ \\
\hline $\mathrm{CARB}_{2 \times}$ & 29 & 21 & -0.800 & 0.132 & -1.059 & -0.542 & -6.1 & $<0.001$ & 55.1 & 41.8 & 65.3 \\
\hline $\mathrm{PROP}_{2 x}$ & 27 & 26 & -0.632 & 0.100 & -0.828 & -0.437 & -6.3 & $<0.001$ & 46.9 & 35.4 & 56.3 \\
\hline TEBU $_{1 \times}$ & 23 & 9 & -0.879 & 0.125 & -1.125 & -0.633 & -7.0 & $<0.001$ & 58.5 & 46.9 & 67.5 \\
\hline $\operatorname{TEBU}_{2 \times}$ & 22 & 13 & -0.760 & 0.089 & -0.934 & -0.586 & -8.6 & $<0.001$ & 53.2 & 44.3 & 60.7 \\
\hline
\end{tabular}

a Active ingredients $\mathrm{CARB}=$ carbendazim, $\mathrm{PROP}=$ propiconazole, TEBU $=$ tebuconazole. Number of applications: $1 \times=$ one spray at early to mid-flowering,

$2 \times=$ first spray at early to mid-flowering and second 7 to 10 days after.

b Total number of treatments evaluated in trials.

$\mathrm{c}$ Total number of trials used in analysis.

${ }^{\mathrm{d}}$ Mean log response ratio $\left(\bar{L}_{\mathrm{IND}}\right)$ for the mean effect of each fungicide treatment on FHB index relative to check mean; standard error of $\bar{L}_{\mathrm{IND}}\left(\mathrm{se}\left(\bar{L}_{\mathrm{IND}}\right)\right)$, lower $\left(C I_{L}\right)$ and upper $\left(C I_{U}\right)$ limits of the $95 \%$ confidence interval around $\bar{L}_{\mathrm{IND}}$

e Mean control efficacy $(\bar{C})$ and lower $\left(C I_{L}\right)$ and upper $\left(C I_{U}\right)$ limits of the $95 \%$ confidence interval around $\bar{C}$ estimated by back-transformation of $\bar{L}_{\mathrm{IND}}$ and lower $\left(C I_{L}\right)$ and upper $\left(C I_{U}\right)$ confidence around $\bar{L}_{\mathrm{IND}}$, as $\bar{C}=\left(1-\exp \left(\bar{L}_{\mathrm{IND}}\right)\right) \times 100$. 
higher mean efficacy than that reported for one spray of the same fungicide in the U.S. study. There may be other factors inherent to the trials that may explain these differences, including the dosage, as in most Brazilian trials the dosage was $150 \mathrm{~g} / \mathrm{a} . \mathrm{i} . / \mathrm{ha}$, which was around $30 \%$ higher than the dosage reported in the U.S. fungicide trials (Paul et al. 2008). Nevertheless, the same trend of TEBU outperforming PROP was found in both studies. Although these two triazoles share a common mode of action, they differ in chemical and physical formulation and also differential sensitivity of pathogen populations to different triazoles (Klix et al. 2007; Liu et al. 2011; Spolti et al. 2014), including PROP, which was shown to present the widest variation in sensitivity levels (Talas and McDonald 2015).
Although our estimate of FHB control efficacy is higher than in the U.S. study, it is still low relative to control efficacy values reported for foliar wheat diseases and the reasons have been discussed previously (McMullen et al. 2012; Paul et al. 2007; Ransom and McMullen 2008). Although the fungicides are highly effective against FHB pathogens in vitro, poor coverage and retention of fungicide on spikes in the field is a known problem, together with asynchrony of tillering, heading, and flowering, which extends the window of vulnerability for infection (Del Ponte et al. 2005; Deuner et al. 2011; McMullen et al. 2012; Wegulo et al. 2015). Therefore, it is expected that under certain environmental and crop conditions and improved spray technology, although less common, control
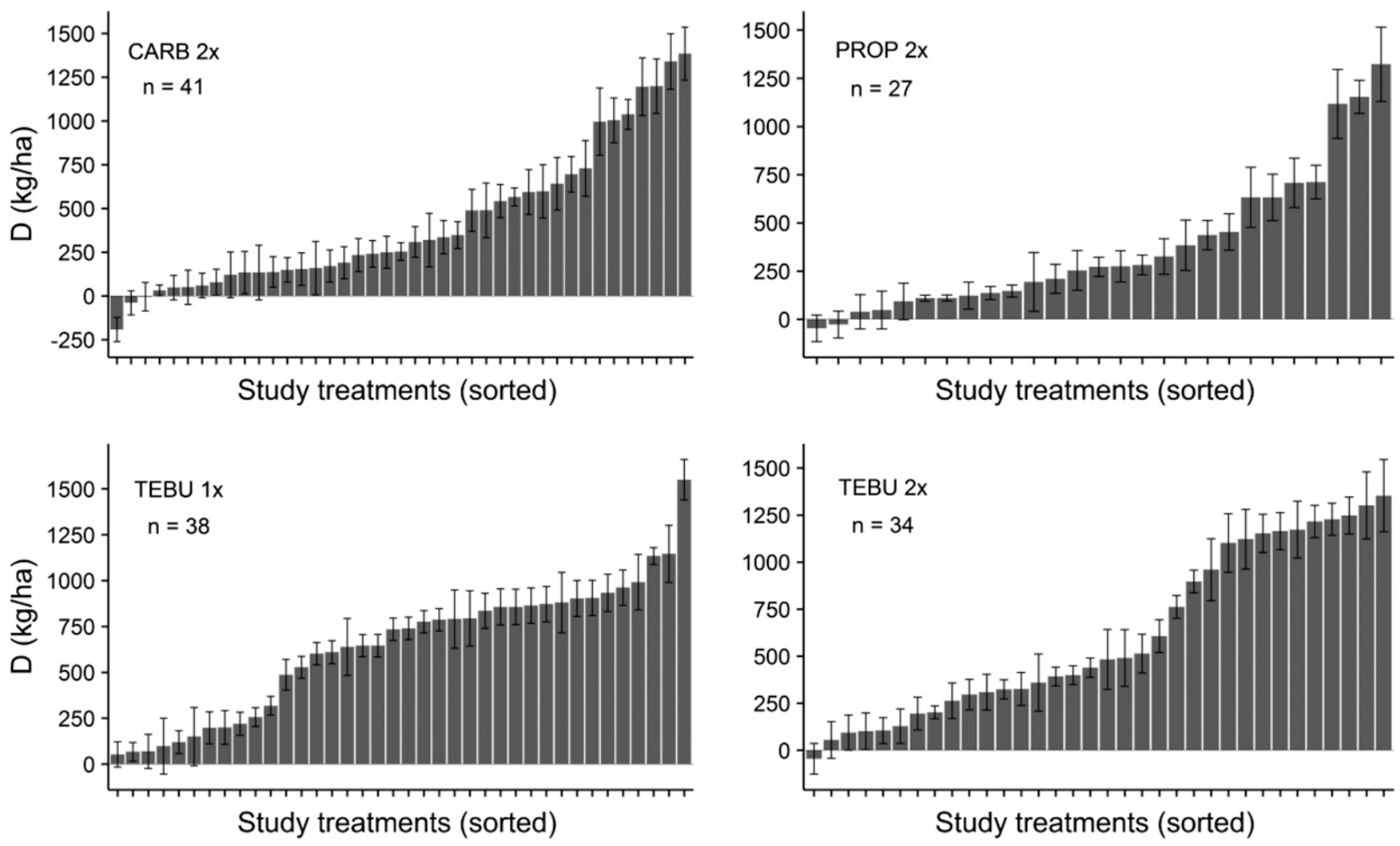

Fig. 3. Distribution (sorted from the lowest to the highest) of the mean differences $(D)$ of grain yield between plots treated with fungicides for the control of Fusarium head blight and nontreated check. Trials were selected based on a systematic review of peer- and non-peer-reviewed studies conducted in Brazil. The four fungicide treatments evaluated were two sprays (first spray at early to mid-flowering and a second 7 to 10 days later) of carbendazim ( $\left.\mathrm{CARB}_{2 \times}\right)$, propiconazole $\left(\mathrm{PROP}_{2 \times}\right)$, or tebuconazole $\left(\mathrm{TEBU}_{2 \times}\right)$, or one spray (early to mid-flowering) of tebuconazole $\left(\mathrm{TEBU}_{1 \times}\right)$. The height of the bar represents $D$ and vertical lines extending from each bar are standard errors. The number ( $\mathrm{n}$ ) of entries (treatments) varied among the fungicides.

Table 3. Mean unstandardized difference $(\bar{D})$ in yield between fungicide-treated and nontreated wheat plots estimated by a network meta-analytic model, calculated percent yield return relative to nontreated plot $(\bar{Y})$, and related statistics for the effect of four fungicide treatments on Fusarium head bight index in trials selected following a systematic review of peer- and non-peer-reviewed studies conducted in southern Brazil from 2000 to 2015

\begin{tabular}{|c|c|c|c|c|c|c|c|c|c|c|c|}
\hline \multirow[b]{2}{*}{ Fungicide $^{\mathbf{a}}$} & \multirow[b]{2}{*}{$n^{\mathbf{b}}$} & \multirow[b]{2}{*}{$k^{\mathbf{c}}$} & \multicolumn{6}{|c|}{ Effect size $^{d}$} & \multicolumn{3}{|c|}{ Yield return $(\%)^{\mathbf{e}}$} \\
\hline & & & $\bar{D}$ & se $(\bar{D})$ & $C I_{L}$ & $C \boldsymbol{I}_{U}$ & $Z$ & $P$ & $\overline{\boldsymbol{Y}}$ & $C I_{L}$ & $C I_{U}$ \\
\hline $\mathrm{CARB}_{2 \times}$ & 41 & 33 & 455.8 & 64.6 & 329.2 & 582.3 & 7.1 & $<0.001$ & 12.8 & 9.3 & 16.3 \\
\hline $\mathrm{PROP}_{2 x}$ & 27 & 26 & 497.4 & 64.8 & 370.4 & 624.4 & 7.7 & $<0.001$ & 16.0 & 12.1 & 20.0 \\
\hline $\mathrm{TEBU}_{1 \times}$ & 38 & 22 & 456.7 & 69.2 & 321.1 & 592.2 & 6.6 & $<0.001$ & 17.3 & 12.5 & 22.4 \\
\hline TEBU $_{2 x}$ & 34 & 25 & 558.3 & 76.5 & 408.38 & 708.1 & 7.3 & $<0.001$ & 19.2 & 14.2 & 24.5 \\
\hline
\end{tabular}

${ }^{a}$ Active ingredients $\mathrm{CARB}=$ carbendazim, $\mathrm{PROP}=$ propiconazole, $\mathrm{TEBU}=$ tebuconazole. Number of applications: $1 \times=$ one spray at early to mid-flowering,

$2 \times=$ first spray at early to mid-flowering and second 7 to 10 days after.

$\mathrm{b}$ Total number of treatments evaluated on trials.

c Total number of trials used in analysis.

${ }^{\mathrm{d}}$ Mean yield difference $(\bar{D})$ for each fungicide treatment relative to check $(\mathrm{kg} / \mathrm{ha})$; standard error of $\bar{D}(\operatorname{se}(\bar{D}))$ lower $\left(C I_{L}\right)$ and upper $\left(C I_{U}\right)$ limits of the $95 \%$ confidence interval around $\bar{D}$.

${ }^{\text {e }}$ Mean percent yield return $(\bar{Y})$ and lower $\left(C I_{L}\right)$ and upper $\left(C I_{U}\right)$ limits of the $95 \%$ confidence interval around $\bar{Y}$ estimated by back-transformation of $\bar{L}_{Y L D}$ and lower $\left(C I_{L}\right)$ and upper $\left(C I_{U}\right)$ confidence around $\bar{L}_{Y L D}$, as $\bar{Y}=\left(\exp \left(\bar{L}_{Y L D}\right)-1\right) \times 100$. 
efficacies higher than $75 \%$ can be achieved as reported in the primary studies (Casa et al. 2007; Ransom and McMullen 2008).

With regards to CARB, we provide here the first meta-analytic summary of this fungicide for FHB control, which has a long use in Brazil (early 1980s) (Deuner et al. 2011). The mean percent control obtained using $\mathrm{CARB}_{2 \mathrm{x}}$ was close to that estimated for TEBU. CARB has been generally reported to be less effective than metconazole and epoxiconazole in previous studies (Chen et al. 2012; Mesterházy et al. 2003) but performed better than PROP in our study as to disease suppression, which corroborate a previous finding (Sun et al. 2014). In China, where CARB is extensively used in FHB management, decline in control efficacy has been reported and associated with the development of resistance to benzimidazoles in the pathogenic population (Chen and Zhou 2009; Chen et al. 2007, 2012, 2015; Zhang et al. 2013). We did not find a trend of decreasing control efficacy over the years for any of the fungicides, concurring with the U.S. study (Paul et al. 2007, 2008). Collectively, these results suggest that resistant populations to these fungicides are less likely to be selected over the years at levels that may affect control efficacy. However, studies in this area are scarce and deserve further investigation as a few Brazilian isolates that exhibiting low sensitivity to these fungicides have been found in regions with intensive use of fungicides (Machado et al., unpublished).

We found that TEBU applied twice, although not improving control efficacy compared with one spray, provided the highest mean absolute/relative yield return $(558 \mathrm{~kg} / \mathrm{ha}$ or $19.2 \%)$ among the treatments. This response is similar to the reports for metconazole applied once in the U.S. study, which provided the highest yield response $(536 \mathrm{~kg} / \mathrm{ha}$ or $19.3 \%)$ in spring wheat. Although TEBU $\mathrm{Hx}_{1 \mathrm{x}}$ performed statistically similar to $\mathrm{TEBU}_{2 \mathrm{x}}$ in our study, the latter added +102 $\mathrm{kg} / \mathrm{ha}$ (or $+2.2 \%$ ). Interestingly, the $457 \mathrm{~kg} /$ ha increase in yield relative to the nontreated check from applying one spray of TEBU in Brazil is $118 \mathrm{~kg} / \mathrm{ha}$ higher than the estimate for TEBU in the U.S. study (Paul et al. 2010), which may be due the aforementioned differences. In our study, although $\mathrm{CARB}_{2 \mathrm{x}}$ outperformed $\mathrm{PROP}_{2 \mathrm{x}}$ with regards to control efficacy (8.2 percentage points higher), yield response to these fungicides was not so far apart, which agrees with studies conducted in China (Sun et al. 2014).

Although data on the intensity of foliar diseases in the trials were not available, the higher yield response to TEBU may be due to its extended effects on other diseases, especially when two sprays were made. In the subtropics of Brazil, epidemics of foliar diseases such as tan spot are very common and may lead to significant yield loss (Danelli et al. 2011; Tonin et al. 2013). Economic benefits of foliar fungicide applications, mainly triazole + strobilurin mixtures, are greater under a more favorable environment for foliar disease severity, such as tan spot and spot blotch (Wegulo et al. 2011). It would be instructive that future trials in Brazil report the intensity of foliar diseases to nontreated check whether the increased grain yield due to two TEBU sprays, while not affecting FHB control efficacy (at least for FHB index assessed visually), is related to foliar disease control.

FHB index in the nontreated check, tested as a continuous variable, and also baseline classes of index and yield, did not affect yield response and control efficacy. Previous studies have shown contradictory results for the effects of fungicide application for FHB suppression under more or less conducive conditions for the disease development (Hollingsworth et al. 2008; Paul et al. 2008; Ransom and McMullen 2008). However, in general, better yield response to
CARB 2x

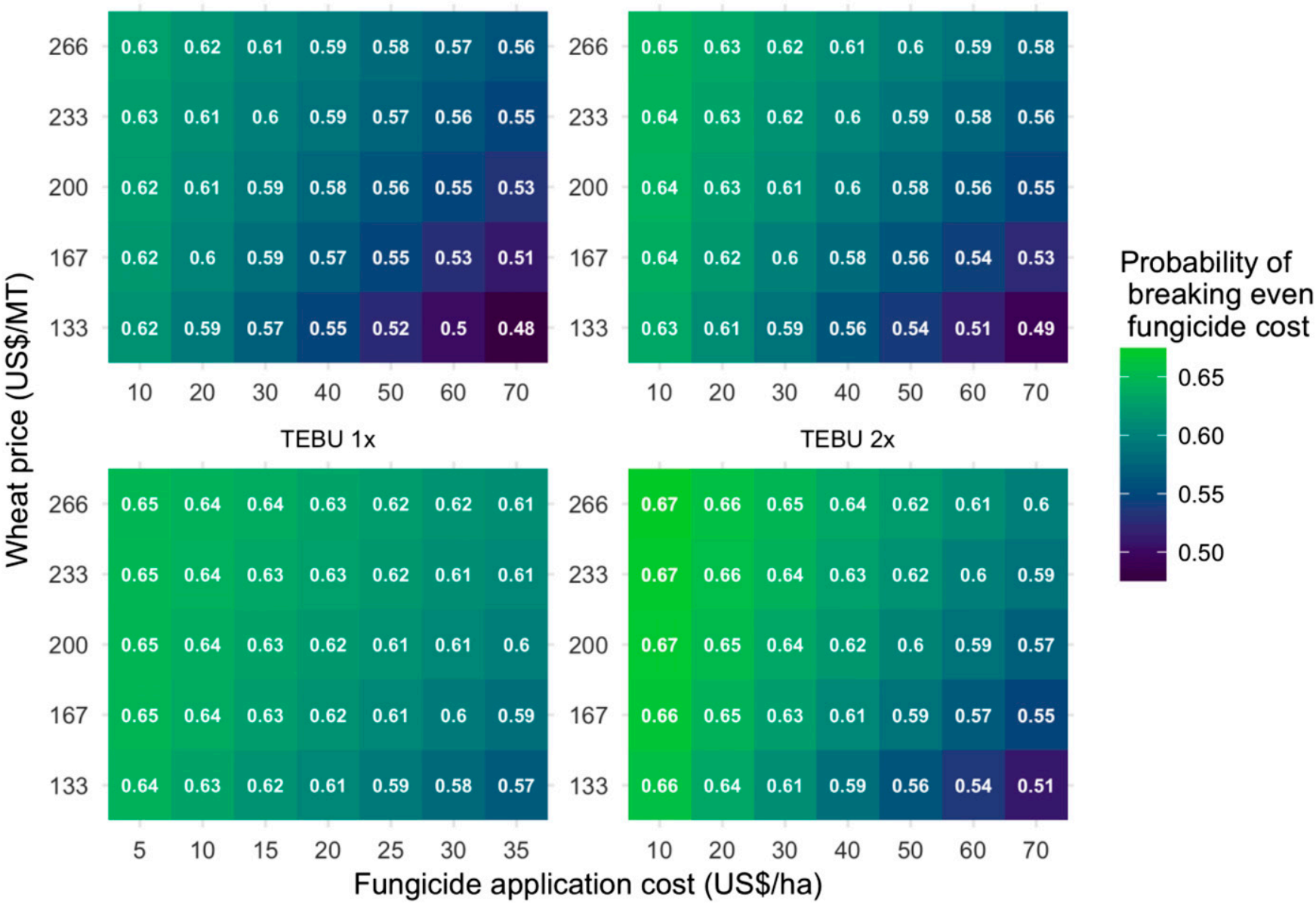

Fig. 4. Heat maps and probability of breaking even on the fungicide investment for a range of costs (product + application) of two sprays (first spray at early to mid-flowering and a second 7 to 10 days later) of carbendazim $\left(\mathrm{CARB}_{2 \times}\right)$, propiconazole $\left(\mathrm{PROP}_{2 \times}\right)$, or tebuconazole $\left(\mathrm{TEBU}_{2 \times}\right)$ or one spray of tebuconazole $\left(\mathrm{TEBU}_{1 \times}\right)$ at early to mid-flowering for the control of Fusarium head blight and a range of wheat prices in selected Brazilian trials based on a systematic review of peer- and non-peer-reviewed studies conducted in Brazil from 2000 to 2015. 
fungicides is more likely to be achieved under conditions more favorable for FHB epidemics (Paul et al. 2010).

It has been generally argued that yield response to a second spray targeting FHB rarely offsets the cost of additional spray (D'Angelo et al. 2014; McMullen et al. 1997; Paul et al. 2010). We found that a second application of TEBU, although not providing significant superior control efficacy, resulted in significant increase in yield compared with one spray. In fact, the large majority of the data used in our study were from trials that evaluated only the effect of two sprays. The entries of one spray of TEBU concentrated in a relatively low number of studies with multiple entries of the one spray treatment, which could affect our results. Previously, the application of TEBU or TEBU + prothioconazole was found to be a profitable strategy for FHB management (Ransom and McMullen 2008; Salgado et al. 2014). The probability of breaking even on the fungicide application costs, although not so high in our study (below $70 \%$ ), did not vary according to the number of applications $(62.7 \%$ and $62.8 \%)$. It should be instructive to further evaluate the effect of two sprays for other important traits such as test weight and mycotoxin, as performed elsewhere (Salgado et al. 2014, 2015).

The comparison between one and two sprays, at least for TEBU and one of the mixtures, should be incorporated in the current protocols of the cooperative trials in Brazil, which currently tests only two sprays. Also, the Brazilian cooperative trials include triazole + strobilurin mixtures as treatments, besides triazoles and carbendazim. Reasons for testing two applications and also the mixtures relate particularly to the need to protect wheat crops against tan spot and leaf rust, which are usually best controlled with triazole + strobilurin mixtures (Blandino et al. 2006, 2011). Such strategy seems specific to the subtropics of Brazil because of the more favorable environment for fungal diseases compared with temperate regions in North America and Europe. In the other regions, strobilurins, mainly azoxystrobin, but also CARB, are not recommended in FHB management due to reports of increased DON levels in fungicide-treated compared with the nontreated check (Blandino et al. 2006; Mesterházy et al. 2003; Zhang et al. 2009). In fact, the strategy of applying triazoles, CARB, or premixes with strobilurins is widespread in southern Brazil where wheat farmers rely on sequential applications, sometimes alternating them between first and second spray (not always the same in both sprays as tested in the trials), to achieve improved control, higher yield, and better wheat prices due to the reduction of DON in harvested grain.

In our review, only four within the selected studies, which tested at least one of the three selected fungicides, reported DON levels in fungicide-treated plots (Santana et al. 2016b, c; Tonin et al. 2014, 2015). As more data on the effect of the fungicides tested in this study but also the triazole + strobilurins premixes with regards to DON reduction become available (Marques et al. 2017; Reynaldo and Machado 2017), further meta-analysis using these data are worthy (Marques et al. 2017; Spolti et al. 2013). In the U.S. study, the percent reduction of DON by TEBU was lower (22.8 percentage points) than for other triazoles performing best with regards control efficacy and DON reduction (Paul et al. 2010). Therefore, the focus on FHB index control efficacy, as performed in our study, is an important step toward optimizing FHB management for DON reduction given that these two measures are correlated (Paul et al. 2006).

\section{Acknowledgments}

The authors thank the Programa de Pós-graduação em Fitopatologia (UFV) and CNPq-Conselho Nacional de Desenvolvimento Científico e Tecnológico for providing a graduate scholarship to F. J. Machado and the CNPq for a research fellowship for E. M. Del Ponte. The authors thank the network of researchers from several Brazilian institutes who contributed data and authored the original publications from where the summary data was obtained for conducting this study.

\section{Literature Cited}

ANVISA. 2011. Resolução RDC n ${ }^{\circ}$ 7, de 18 de fevereiro de 2011. Dispõe sobre limites máximos tolerados (LMT) para micotoxinas emalimentos. Page 66 in: Diário Oficial da União, Poder Executivo, Brasília, 26 fev. 2011. Seção 1 .
Blandino, M., Minelli, L., and Reyneri, A. 2006. Strategies for the chemical control of Fusarium head blight: effect on yield, alveographic parameters and deoxynivalenol contamination in winter wheat grain. Eur. J. Agron. 25: 193-201.

Blandino, M., Pascale, M., Haidukowski, M., and Reyneri, A. 2011. Influence of agronomic conditions on the efficacy of different fungicides applied to wheat at heading: effect on flag leaf senescence, Fusarium head blight attack, grain yield and deoxynivalenol contamination. Ital. J. Agron. 6:204-211.

Borenstein, M., Hedges, L. V., Higgins, J. P. T., and Rothstein, H. R. 2009. Introduction to Meta-Analysis. John Wiley \& Sons, Chichester, U.K.

Casa, R. T., Bogo, A., Moreira, E. N., and Kuhnem, P. R., Jr. 2007. Época de aplicação e desempenho de fungicidas no controle da giberela em trigo. Cienc. Rural 37:1558-1563.

Chen, C., Wang, J., Luo, Q., Yuan, S., and Zhou, M. 2007. Characterization and fitness of carbendazim-resistant strains of Fusarium graminearum (wheat scab). Pest Manag. Sci. 63:1201-1207.

Chen, Y., Yang, X., Gu, C.-Y., Zhang, A.-F., Gao, T.-C., and Zhou, M.-G. 2015. Genotypes and phenotypic characterization of field Fusarium asiaticum isolates resistant to carbendazim in Anhui province of China. Plant Dis. 99: 342-346.

Chen, Y., Zhang, A.-F., Gao, T.-C., Zhang, Y., Wang, W.-X., Ding, K.-J., Chen, L., Sun, Z., Fang, X.-Z., and Zhou, M.-G. 2012. Integrated use of pyraclostrobin and epoxiconazole for the control of Fusarium head blight of wheat in Anhui Province of China. Plant Dis. 96:1495-1500.

Chen, Y., and Zhou, M.-G. 2009. Characterization of Fusarium graminearum isolates resistant to both carbendazim and a new fungicide JS399-19. Phytopathology 99:441-446.

Correa, D., Marco, J., Jr., and Nakai, E. H. 2012. Desempenho de diferentes formulações de fungicidas no controle da giberela do trigo. Acta Iguazu 1: 72-77.

Danelli, A. L. D., Reis, E. M. and Fialhos, F. R. G. 2011. Etiologia e intensidade de manchas foliares em cultivares de trigo em três locais do Rio Grande do Sul, Brasil. Scientia Agropecuaria 2:149-155.

D’Angelo, D. L., Bradley, C. A., Ames, K. A., Willyerd, K. T., Madden, L. V., and Paul, P. A. 2014. Efficacy of fungicide applications during and after anthesis against Fusarium head blight and deoxynivalenol in soft red winter wheat. Plant Dis. 98:1387-1397.

De Wolf, E. D., Madden, L. V., and Lipps, P. E. 2003. Risk assessment models for wheat Fusarium head blight epidemics based on within-season weather data. Phytopathology 93:428-435.

Del Ponte, E. M., Fernandes, J. M. C., and Bergstrom, G. C. 2007. Influence of growth stage on Fusarium head blight and deoxynivalenol production in wheat. J. Phytopathol. 155:577-581.

Del Ponte, E. M., Fernandes, J. M. C., and Pavan, W. 2005. A risk infection simulation model for Fusarium head blight of wheat. Fitopatol. Bras. 30:634-642.

Del Ponte, E. M., Garda-Buffon, J., and Badiale-Furlong, E. 2012. Deoxynivalenol and nivalenol in commercial wheat grain related to Fusarium head blight epidemics in southern Brazil. Food Chem. 132:1087-1091.

Deuner, C. C. 2009. Eficácia agronômica de fungicidas no controle de giberela na cultura do trigo. Pages 269-274 in: Controle de doenças em plantas. FUNDACEP 1993-2008. Resultados de pesquisa. Acervo histórico. Divulgação técnica $\mathrm{N}^{\circ}$ 3. Cruz Alta.

Deuner, C. C., Viana, E., De Rossi, R. L., and Camera, J. 2011. Fungicidas indicados pela pesquisa, momento da aplicação e eficiência do controle de giberela na cultura do trigo. Pages 215-234 in: Seminário sobre giberela em cerais de inverno: coletânea de trabalhos (p.). E. M. Reis, ed. Berthier, Passo Fundo, Brazil.

Feksa, H. R., Gardiano, C. G., Duhatschek, B., Proença, C., and Tessmann, D. J. 2014a. Ensaio manejo químico de giberela na cultura do trigo cultivar BRS Guamirim. In: Proceedings of Reunião da comissão brasileira de pesquisa de trigo e triticale (CD-ROM).

Feksa, H. R., Gardiano, C. G., Duhatschek, B., Proença, C., and Tessmann, D. J. 2014b. Ensaio manejo químico de giberela na cultura do trigo cultivar CD 105 In: Proceedings of Reunião da comissão brasileira de pesquisa de trigo e triticale (CD-ROM). Embrapa Trigo, Passo Fundo, Brazil.

Feldmann, N. A., Mühl, F. R., Hahn, L., Hoffmann, J. T. R., Klein, R., Zambiazi, M. P., Martini, A., Jantsch, M., and Lima, L. 2014. Avaliação de fungicidas no controle de giberela do trigo. In: Proceedings of Reunião da comissão brasileira de pesquisa de trigo e triticale (CD-ROM). Embrapa Trigo, Passo Fundo, Brazil.

Gilbert, J., and Haber, S. 2013. Overview of some recent research developments in Fusarium head blight of wheat. Can. J. Plant Pathol. 35:149-174.

Goswami, R. S., and Kistler, H. C. 2004. Heading for disaster: Fusarium graminearum on cereal crops. Mol. Plant Pathol. 5:515-525.

Hollingsworth, C. R., Motteberg, C. D., Wiersma, J. V., and Atkinson, L. M. 2008 Agronomic and economic responses of spring wheat to management of Fusarium head blight. Plant Dis. 92:1339-1348.

Klix, M. B., Verreet, J. A., and Beyer, M. 2007. Comparison of the declining triazole sensitivity of Gibberella zeae and increased sensitivity achieved by advances in triazole fungicide development. Crop Prot. 26:683-690.

Liu, X., Yu, F., Schnabel, G., Wu, J., Wang, Z., and Ma, Z. 2011. Paralogous cyp51 genes in Fusarium graminearum mediate differential sensitivity to sterol demethylation inhibitors. Fungal Genet. Biol. 48:113-123. 
Madden, L. V., and Paul, P. A. 2011. Meta-analysis for evidence synthesis in plant pathology : an overview. Phytopathology 101:16-30.

Madden, L. V., Piepho, H.-P., and Paul, P. A. 2016. Statistical models and methods for network meta-analysis. Phytopathology 106:792-806.

Marques, L. N., Pizzutti, I. R., Balardin, R. S., Santos, I. D., Dias, J. V., Stefanello, M. T., and Serafini, P. T. 2017. Occurrence of mycotoxins in wheat grains exposed to fungicides on Fusarium head blight control in southern Brazil. J. Environ. Sci. Health B 12:1-7.

McMullen, M., Jones, R., and Gallenberg, D. 1997. Scab of wheat and barley: a re-emerging disease of devastating impact. Plant Dis. 81:1340-1348.

McMullen, M. P., Bergstrom, G. C., De Wolf, E., Dill-Macky, R., Hershman, D. E., Shaner, G., and Van Sanford, D. 2012. A unified effort to fight an enemy of wheat and barley: Fusarium head blight. Plant Dis. 96:1712-1728.

Mesterházy, Á., Bartók, T., and Lamper, C. 2003. Influence of wheat cultivar, species of Fusarium, and isolate aggressiveness on the efficacy of fungicides for control of Fusarium head blight. Plant Dis. 87:1107-1115.

Ngugi, H. K., Lehman, B. L., and Madden, L. V. 2011. Multiple treatment metaanalysis of products evaluated for control of fire blight in the eastern United States. Phytopathology 101:512-522.

Ojiambo, P. S., Paul, P. A., and Holmes, G. J. 2010. A quantitative review of fungicide efficacy for managing downy mildew in cucurbits. Phytopathology 100:1066-1076.

Panisson, E., Boller, W., Reis, E. M., and Hoffmann, L. 2003. Técnicas de aplicação de fungicida em trigo para o controle de giberela (Gibberella zeae). Cienc. Rural 33:13-20.

Panisson, E., Reis, E. M., and Boller, W. 2002. Efeito de época, do número de aplicações e de doses de fungicida no controle da giberela em trigo. Fitopatol. Bras. 27:489-494.

Paul, P. A., Lipps, P. E., Hershman, D. E., McMullen, M. P., Draper, M. A., and Madden, L. V. 2007. A quantitative review of tebuconazole effect on Fusarium head blight and deoxynivalenol content in wheat. Phytopathology 97:211-220.

Paul, P. A., Lipps, P. E., Hershman, D. E., McMullen, M. P., Draper, M. A., and Madden, L. V. 2008. Efficacy of triazole-based fungicides for Fusarium head blight and deoxynivalenol control in wheat: A multivariate meta-analysis. Phytopathology 98:999-1011.

Paul, P. A., Lipps, P. E., and Madden, L. V. 2006. Meta-analysis of regression coefficients for the relationship between Fusarium head blight and deoxynivalenol content of wheat. Phytopathology 96:951-961.

Paul, P. A., Madden, L. V., Bradley, C. A., Robertson, A. E., Munkvold, G. P., Shaner, G., Wise, K. A., Malvick, D. K., Allen, T. W., Grybauskas, A., Vincelli, P., and Esker, P. 2011. Meta-analysis of yield response of hybrid field corn to foliar fungicides in the U.S. Corn Belt. Phytopathology 101:1122-1132.

Paul, P. A., McMullen, M. P., Hershman, D. E., and Madden, L. V. 2010. Meta-analysis of the effects of triazole-based fungicides on wheat yield and test weight as influenced by Fusarium head blight intensity. Phytopathology 100:160-171.

Piepho, H.-P., Madden, L. V., and Williams, E. R. 2015. Multiplicative interaction in network meta-analysis. Stat. Med. 34:582-594.

R Core Team. 2012. R: A language and environment for statistical computing. $\mathrm{R}$ Foundation for Statistical Computing, Vienna, Austria. Online at http://www.Rproject.org/.

Ransom, J. K., and McMullen, M. V. 2008. Yield and disease control on hard winter wheat cultivars with foliar fungicides. Agron. J. 100:1130-1137.

Reynaldo, E. F., and Machado, T. M. 2017. Performance of spray nozzles to control Fusarium head blight and mycotoxin in the barley crop. Rev. Bras. Eng. Agric. Ambient. 21:209-213.

Salgado, J. D., Madden, L. V., and Paul, P. A. 2014. Efficacy and economics of integrating in-field and harvesting strategies to manage Fusarium head blight of wheat. Plant Dis. 98:1407-1421.

Salgado, J. D., Madden, L. V., and Paul, P. A. 2015. Quantifying the effects of Fusarium head blight on grain yield and test weight in soft red winter wheat. Phytopathology 105:295-306.

Santana, F. M., Lau, D., Aguilera, J. G., Sbalcheiro, C. C., Feksa, H., Floss, L. G., and Guterres, C. W. 2016a. Eficiência de fungicidas para controle de Gibberella zeae em trigo: resultados dos Ensaios Cooperativos - Safra 2013. Comunicado Técnico 362. Embrapa Trigo, Passo Fundo, Brazil.

Santana, F. M., Lau, D., Cargnin, A., Seixas, C. D. S., Schipanski, C. A., Feksa, H. R., Wesp, C., Blum, M., and Bassoi, M. C. 2014. Eficiência de fungicidas para controle de giberela em trigo: resultados dos ensaios cooperativos - safra 2012. Comunicado Técnico 336. Embrapa Trigo, Passo Fundo, Brazil.

Santana, F. M., Lau, D., Maciel, J. L. N., Cargnin, A., Seixas, C. D. S., Bassoi, M. C., Schipanski, C. A., Feksa, H., Casa, R. T., Wesp, C., Navarini, L., and Blum, M. 2012. Eficiência de fungicidas para controle de giberela em trigo: resultados dos ensaios cooperativos - safra 2011. Comunicado Técnico 23. Embrapa Trigo, Passo Fundo, Brazil.

Santana, F. M., Lau, D., Sbalcheiro, C. C., Feksa, H., Guterres, C. W., and Venâncio, W. S. 2016b. Eficiência de fungicidas para controle de Gibberella zeae em trigo: resultados dos Ensaios Cooperativos - Safra 2015. Comunicado Técnico 368. Embrapa Trigo, Passo Fundo, Brazil.

Santana, F. M., Lau, D., Sbalcheiro, C. C., Schipanski, C. A., Seixas, C. D. S., Feksa, H., Floss, L. G., Guterres, C. W., and Venâncio, W. S. 2016c. Eficiência de fungicidas para controle de Gibberella zeae em trigo: resultados dos Ensaios Cooperativos - Safra 2014. Comunicado Técnico 364. Embrapa Trigo, Passo Fundo, Brazil.

Scherm, H., Christiano, R. S. C., Esker, P. D., Del Ponte, E. M., and Godoy, C. V. 2009. Quantitative review of fungicide efficacy trials for managing soybean rust in Brazil. Crop Prot. 28:774-782.

Silva, M. S., Rockenbach, D., Pires, F., and Neto, N. 2010. Manejo de fungicidas para o controle de giberela (Gibberellazeae Schw. Petch.) na cultura do trigo. In: Proceedings of Seminário Interinstitucional de Ensino, Pesquisa e Extensão. XIII Mostra de Iniciação Científica. VIII Mostra de Extensão. Unicruz, Cruz Alta, Brazil.

Spolti, P., Del Ponte, E. M., Dong, Y., Cummings, J. A., and Bergstrom, G. C 2014. Triazole sensitivity in a contemporary population of Fusarium graminearum from New York wheat and competitiveness of a tebuconazoleresistant isolate. Plant Dis. 98:607-613.

Spolti, P., Guerra, D. S., Badiale-Furlong, E., and Del Ponte, E. M. 2013. Single and sequential applications of metconazole alone or in mixture with pyraclostrobin to improve Fusarium head blight control and wheat yield in Brazil. Trop. Plant Pathol. 38:85-96.

Spolti, P., Shah, D. A., Fernandes, J. M. C., Bergstrom, G. C., and Del Ponte, E. M. 2015. Disease risk, spatial patterns, and incidence-severity relationships of Fusarium head blight in no-till spring wheat following maize or soybean. Plant Dis. 99:1360-1366.

Sun, H.-Y., Zhu, Y.-F., Liu, Y.-Y., Deng, Y.-Y., Li, W., Zhang, A.-X., and Chen, H.-G. 2014. Evaluation of tebuconazole for the management of Fusarium head blight in China. Australas. Plant Pathol. 43:631-638.

Talas, F., and McDonald, B. A. 2015. Significant variation in sensitivity to a DMI fungicide in field populations of Fusarium graminearum. Plant Pathol. 64: 664-670.

Tedford, E. C., Kriss, A. B., Geater, C., Saini, M., Battles, B., Smelser, R. B., and Fithian, W. A. 2017. Plot size can influence yield benefits from fungicides on corn. Crop Prot. 91:66-73.

Tonin, R. F. B., Reis, E. M., and Danelli, A. L. D. 2013. Etiologia e quantificação dos agentes causais de manchas foliares na cultura do trigo nas safras 2008 a 2011. Summa Phytopathol. 39:102-109.

Tonin, I., Rosa, A. C., Rosa Filho, O., Lemes, C., Tonin, R. B., Deon, A., and Valério, I. P. 2014. Efeito de fungicidas pós-florescimento do trigo no rendimento de grãos e níveis de desoxinivalenol. In: Proceedings of Reunião da comissão brasileira de pesquisa de trigo e triticale (CD-ROM). Embrapa Trigo, Passo Fundo, Brazil.

Tonin, I., Rosa, A. C., Rosa Filho, O., Lemes, C., Tonin, R. B., Deon, A., and Valério, I. P. 2015. Efeito de aplicações extras de fungicidas na fase de florescimento do trigo no rendimento de grãos e níveis de desoxinivalenol. In: Proceedings of Reunião da comissão brasileira de pesquisa de trigo e triticale (CD-ROM). Embrapa Trigo, Passo Fundo, Brazil.

van Egmond, H. P., Schothorst, R. C., and Jonker, M. A. 2007. Regulations relating to mycotoxins in food: perspectives in a global and European context. Anal. Bioanal. Chem. 389:147-157.

Viechtbauer, W. 2010. Conducting Meta-Analyses in R with the metafor Package. J. Stat. Softw. 36:1-48.

Wegulo, S. N., Baenziger, P. S., Nopsa, J. H., Bockus, W. W., and Hallen-Adams, H. 2015. Management of Fusarium head blight of wheat and barley. Crop Prot. 73:100-107.

Wegulo, S. N., Zwingman, M. V., Breathnach, J. A., and Baenziger, P. S. 2011. Economic returns from fungicide application to control foliar fungal diseases in winter wheat. Crop Prot. 30:685-692.

Willyerd, K. T., Li, C., Madden, L. V., Bradley, C. A., Bergstrom, G. C., Sweets, L. E., McMullen, M., Ransom, J. K., Grybauskas, A., Osborne, L., Wegulo, S. N., Hershman, D. E., Wise, K., Bockus, W. W., Groth, D., Dill-Macky, R., Milus, E., Esker, P. D., Waxman, K. D., Adee, E. A., Ebelhar, S. E., Young, B. G., and Paul, P. A. 2012. Efficacy and stability of integrating fungicide and cultivar resistance to manage Fusarium head blight and deoxynivalenol in wheat. Plant Dis. 96:957-967.

Zhang, L., Jia, X., Chen, C., and Zhou, M. 2013. Characterization of carbendazim sensitivity and trichothecene chemotypes of Fusarium graminearum in Jiangsu Province of China. Physiol. Mol. Plant Pathol. 84:53-60.

Zhang, Y. J., Fan, P. S., Zhang, X., Chen, C. J., and Zhou, M. G. 2009. Quantification of Fusarium graminearum in harvested grain by real-time polymerase chain reaction to assess efficacies of fungicides on Fusarium head blight, deoxynivalenol contamination, and yield of winter wheat. Phytopathology 99:95-100. 